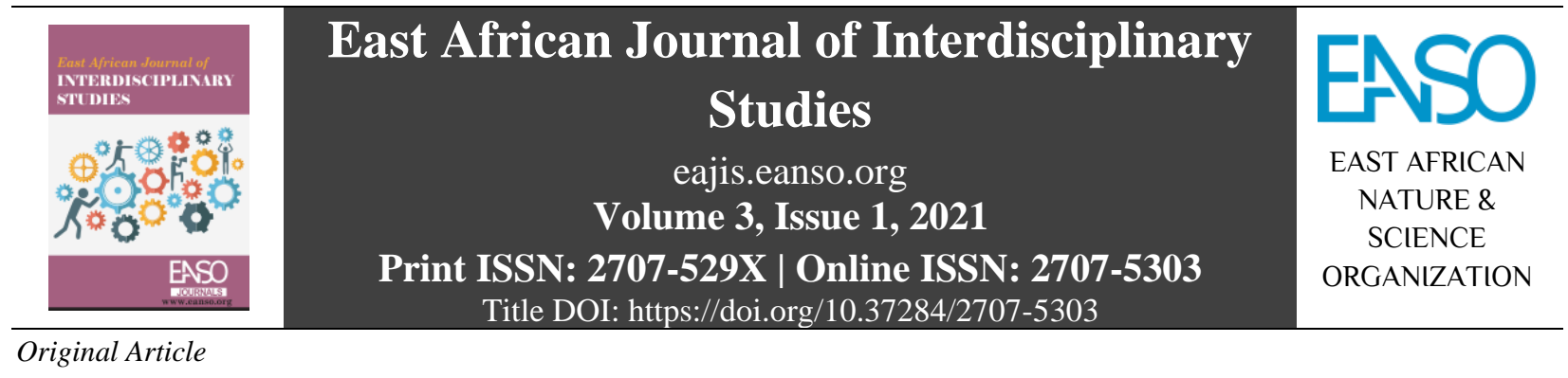

\title{
Common Dressing Styles and Attributes Associated with Students' Dressing Styles in Kenyan Public Universities
}

\author{
Otieno Gladys Akinyi ${ }^{1 *}$, Susan Abong'o, $\mathrm{PhD}^{1} \&$ Keren Mburugu, $P h D^{2}$ \\ ${ }^{1}$ Department of Art and Design, Maseno University, P. O. Box 3275 - 40100, Kisumu, Kenya. \\ ${ }^{2}$ Department of Fashion Design and Marketing, Kenyatta University, P. O. Box 43844 - 00100, Nairobi, Kenya. \\ * Author for Correspondence Email: gladotieno04@yahoo.com.com.
}

Article DOI: https://doi.org/10.37284/eajis.3.1.264

\section{Date Published: ABSTRACT}

07 January 2021 The study sought to examine students' dressing styles and common attributes assigned to them. A descriptive survey design was used in this

Keywords: study. The study areas were the University of Nairobi, Egerton University, Moi University, Technical University of Mombasa, Maseno

Dressing Style, Modesty, and Karatina Universities. Multiple sampling procedures were used to select 566 students who participated in the study. Data were collected Attributes, using questionnaires, focus group discussions and observation

Public Universities,

Kenya. checklists. Results show that majority of respondents bought their own clothes with funds provided by the parents or guardians. The most outstanding feature that informed choice of dress was aesthetics, followed by comfort and design. Vests, bare chest tops and shorts were considered modest while high-slitted skirts, miniskirts, unbuttoned shirts, boob-tops, tumbo-cuts, skin-tight dresses and trousers and Bermuda shorts were found to be immodest. Recommendations have been made to develop guidelines on the choice of dress for students in institutions of higher learning to enhance personal grooming.

\section{APA CITATION}

Akinyi, O. G., Abong'o, S., \& Mburugu, K. (2021). Common Dressing Styles and Attributes Associated with Students' Dressing Styles in Kenyan Public Universities. East African Journal of Interdisciplinary Studies, 3(1), 1-11. https://doi.org/10.37284/eajis.3.1.264

\section{CHICAGO CITATION}

Akinyi, Otieno Gladys, Susan Abong'o, and Keren Mburugu. 2021. "Common Dressing Styles and Attributes Associated with Students' Dressing Styles in Kenyan Public Universities”. East African Journal of Interdisciplinary Studies 3 (1), 1-11. https://doi.org/10.37284/eajis.3.1.264. 


\section{HARVARD CITATION}

Akinyi, O. G., Abong'o, S., and Mburugu, K. (2021) “Common Dressing Styles and Attributes Associated with Students' Dressing Styles in Kenyan Public Universities", East African Journal of Interdisciplinary Studies, 3(1), pp. 1-11. doi: 10.37284/eajis.3.1.264.

\section{IEEE CITATION}

O. G. Akinyi, S. Abong'o, and K. Mburugu, "Common Dressing Styles and Attributes Associated with Students' Dressing Styles in Kenyan Public Universities”, EAJIS, vol. 3, no. 1, pp. 1-11, Jan. 2021.

\section{MLA CITATION}

Akinyi, Otieno Gladys, Susan Abong'o, and Keren Mburugu. "Common Dressing Styles and Attributes Associated with Students' Dressing Styles in Kenyan Public Universities”. East African Journal of Interdisciplinary Studies, Vol. 3, no. 1, Jan. 2021, pp. 1-11, doi:10.37284/eajis.3.1.264.

\section{INTRODUCTION}

Clothing has always been considered as a form of non-verbal and powerful means of communication (Todorovic, Cuden, Kosak and Toporisic, 2017; Tijana, Tomaz and Cuden, 2014; Grammer, Renninger, and Fisher, 2004; Ehrich, 1994; Barnes and Eicher, 1992; Storm, 1987). Many people believe that several types of communication can be performed through garments worn by individuals (Todorovic et al., 2017; Lennon et al., 2014). Clothing communicates about the wearer and first impressions can be heavily influenced by the messages conveyed by dress (Howlet et al., 2013). People are accustomed to thinking about clothes in a fairly routine and almost unconscious way. Only when attention is drawn to them, do people realise that they are actively analysing clothes (Rudd and Lennon, 2001; Kaiser, 1997). Both men and women deal with decisions related to their own clothes and interpretations of other people's appearances, on a daily basis. With garments, for example, one can make a statement about age, gender, social class, school, affiliation, or religion.

A person's choice of clothing heavily influences the impression they transmit, hence is a powerful communication tool (Howlet et al., 2013). According to Lennon (1990) and
Lennon, Fairhurst and Peatross (1991), the clothing individual wear affects judgment about the individual, as well as behavioural responses toward the person. Further, Howlet et al. (2013) state that appearance, posture and dress have all been found to communicate a range of personality traits, occupational and social roles. It is acknowledged that whenever people encounter each other for the first time, they know very little about each other (Pongo and Obinnim, 2016). However, it is the clothing worn that conveys the information that people use to make inferences about personality (Damhorst, 1990). According to Awasthi (2017) and Lennon, Schultz and Johnson (1999), dress conveys accurate and inaccurate messages about the wearer. Every day, people form first impressions of others; they do so rapidly and effortlessly, and complex judgments are made based on appearance in less than half a second (Olivola and Todorov, 2010). The clothes send different messages to the people that one may interact with. Garments worn give other people cues about one's social status, occupation, or personality (Howlet et al., 2013; Johnson, Schofield and Yurchisin, 2002; Kefgen and Touchie-Specht, 1981) and the inferences are made and attributes assigned about personality. 
Clothing choices are often driven by one's activities. When choosing styles of garments, it is often advisable to consider personal body build, appearance and those that fall within the trend of fashion (Liddel and Samuels, 2004; Butler, 1975). However, since the 1970s, the dressing styles of the youth have been described as symbolic of individual expression which is considered a rejection of the artificial look of the affluent society, classlessness and functionality (Kaiser, 1985). Since then, the youth have tried to be unisexual in their dressing styles. Some males symbolise their rejection of sex norms and masculine dress by adopting such styles as long hair and beards, and unisexual garments such as jeans and Tshirts that represents equality between them. The girls in turn have adopted short or cleanshaven hair and garments such as jeans and shorts. Probably through the male and female youth's dressing styles described above, they find them to hold less polarised views of masculinity and femininity and may be less likely to stereotype according to sex roles.

In the past, most universities tolerated all manner of the dress by students.

Currently, some pressure groups are urging universities to regulate what students wear. In several public universities in Nigeria, for example, students are forced to adhere to specific dress codes to be allowed to enter lecture rooms or to sit examinations. In Uganda, Islamic University leads the clamour for a dress code while Makerere University and Kyambogo University are on course to institute the same. In Kenya Strathmore, a private university enforces a dress code that bars students from entering the campus wearing miniskirts, tight dresses, jeans and t-shirts or slippers. This is based on the motto of many business schools in the world that those seeking careers in accounting and finance have no business wearing fashions picked from the soap operas.

\section{METHODS}

A descriptive survey design was used in this study. The study area consisted of the University of Nairobi, Egerton University, Kenyatta University, Moi University, Technical University of Mombasa, Maseno University and Karatina University. The study employed multiple sampling procedures. First, purposive sampling was used to select the main campuses of the University of Nairobi, Egerton University, Kenyatta University, Moi University, Technical University of Mombasa, Karatina University and Maseno University that formed the strata. Secondly, the $2^{\text {nd }}$ and $3^{\text {rd }}$-year students were proportionately selected from the faculties represented at the main campus of each university to get a final sample of 566 students. Proportionate numbers were derived from each stratum so that 155 respondents were derived from the University of Nairobi, 102 respondents from Egerton University, 94 from Kenyatta University, 78 from Moi University, 66 from Technical University of Mombasa, 55 from Maseno University and 50 from Karatina University.

The investigations were carried out using questionnaires, focus group discussions and observation checklists to meet the objectives. The questionnaires were designed to include both closed and open-ended questions. Focus Group Discussion Schedule was designed to include open-ended questions. The focus groups were formed in groups of 12, with two each for male and female, from each university. 
The groups were randomly selected from the 2nd and $3^{\text {rd }}$ years that belong to the peer educator's club. The discussions were arranged to take place at a convenient time that did not interfere with the students' classes. The discussions were recorded on tape after seeking permission from the participants. This was to allow the moderator to focus on the discussion, at the same time not miss important points by trying to write them down. Efforts were made to make the group discussions free-flowing with the participation of all members of the group. During the data collection period, observations were made to identify common dressing styles among university students. The observations were plotted on the Observation Checklist. Descriptive statistics were used to summarise the data. Cross tabulations were done to compare the responses between males and females. The qualitative data were grouped into themes and analysed textually and quantitatively.

\section{RESULTS}

\section{Demographic Information of the Respondents}

Demographic information of the respondents is important because it can explain certain outcomes of the results. Out of the 600 students requested to participate in the study, 566 $(94.3 \%)$ respondents voluntarily participated in the study. Of this number, a higher number of males $(51.6 \%)$ than females $(48.4 \%)$ filled the questionnaires (See Table 1). This can be attributed to the fact that some of the female respondents were just not interested in filling the questionnaires. Also, if they have been victims of sexual harassment, they might find it difficult to talk about it. Most of the respondents $(52.9 \%)$ fell in the age group of 2225 . Of these, $62.5 \%$ were males that age group. This is the common age group of undergraduate university students in Kenya. Most females (61.8\%) fell in the age group of 18-21 years. The majority of the respondents (79.1\%) reside on campus. However, more males $(51.4 \%)$ than females $(48.6 \%)$ reside on campus (See Table 1). This can be ascribed to the fact that more males than females responded to the questionnaires. Also, very few of both genders reside at home. This can be attributed to the fact that it is convenient to reside within the campus as the students have access to the library, classrooms and other university utilities available for use.

Table 1: Respondents by Gender, Age and Area of Residence

\begin{tabular}{lllllll}
\hline & Male & & Female & \multicolumn{3}{c}{ Total } \\
\hline Age Category in Years & $\mathbf{( n = 2 8 8 )}$ & $\mathbf{\%}$ & $\mathbf{( n = 2 7 2 )}$ & $\mathbf{\%}$ & $\mathbf{( n = 5 6 0 )}$ & $\mathbf{\%}$ \\
Under 18 & 2 & 100 & 0 & 0 & 2 & 0.4 \\
$18-21$ & 96 & 38.3 & 155 & 61.8 & 251 & 44.8 \\
$22-25$ & 185 & 62.5 & 111 & 37.5 & 296 & 52.9 \\
26 and above & 5 & 45.5 & 6 & 54.5 & 11 & 1.9 \\
\hline Area of residence & $\mathbf{( n = 2 8 9 )}$ & & $\mathbf{( n = 2 7 2 )}$ & & $\mathbf{( n = 5 6 1 )}$ & \\
On-campus & 228 & 51.4 & 216 & 48.6 & 444 & 79.1 \\
Out campus/Non-resident & 50 & 53.2 & 44 & 46.8 & 94 & 16.8 \\
At home & 11 & 47.8 & 12 & 52.2 & 23 & 4.1 \\
\hline
\end{tabular}


Person Responsible for Buying Clothes

The results point that majority $(90.2 \%)$ of the respondents bought their own clothes. Only 9.8 $\%$ had clothes bought for them. An individual who buys his or her own clothes has the freedom to choose whatever is appealing to him or her. Besides, university students have independence in college and would not like to have their parents or guardians choosing clothes for them. That $9.8 \%$ who had clothes bought for them were asked to indicate who was responsible for doing so. The results are presented in Table 2.

Table 2: Person Responsible for Buying the Respondents' Clothes

\begin{tabular}{lll}
\hline Person responsible for buying the clothes & n & \% \\
\hline Father/Mother/Guardian & 49 & 8.6 \\
Other siblings & 1 & 0.2 \\
Relatives & 1 & 0.2 \\
Girlfriends/Friends & 4 & 0.7 \\
No response & 511 & 90.3 \\
\hline TOTAL & $\mathbf{5 6 6}$ & $\mathbf{1 0 0}$ \\
\hline
\end{tabular}

Of those who did not buy their own clothes, $8.6 \%$ indicated that their parents or guardians bought the clothes.

\section{Provision of Funds for Buying Clothes}

The respondents were asked to indicate who provides the funds for buying clothes and a variety of responses came up. The majority
(53.5\%) of the respondents who bought their own clothes had the funds provided by the parents followed by part-time jobs or savings (28.4\%) made by the respondents (see Table 3). The least mentioned source of funds was boyfriends, sugar daddies, or sugar mummies $(1.5 \%)$. These results were expected because, at this age, the respondents are still dependent on their parents for most of their needs.

\section{Table 3: Respondents by Sources of Funds for Buying Clothes}

\begin{tabular}{lll}
\hline Source of Funds & n & \% \\
\hline Parents/Father/Mother/Guardian & 303 & 53.5 \\
Self/Part-time jobs/Hustling/Pocket money/Savings & 161 & 28.5 \\
HELB Loan/Bursary & 58 & 10.2 \\
Boyfriends/Girlfriends/Sugar daddy/Sugar memory & 9 & 1.6 \\
Brother/Siblings/Relatives & 22 & 3.9 \\
N/A or None of your business & 13 & 2.3 \\
Total & $\mathbf{5 6 6}$ & $\mathbf{1 0 0}$ \\
\hline
\end{tabular}

On the other hand, the respondents who do not buy their own clothes were asked to mention the individuals who buy them clothes. The results are given in Table 4. 
Table 4: Respondents by the people who buy them clothes

\begin{tabular}{lll}
\hline Buyer of Clothes & $(\mathbf{n = 1 1 6})$ & \% \\
\hline Father/Mother/Parents/Guardian & 49 & 42.2 \\
Older siblings & 1 & 0.9 \\
Relatives & 1 & 0.9 \\
Girlfriends/Friends & 4 & 3.4 \\
No response & 61 & 52.6 \\
\hline
\end{tabular}

Of the respondents who don't buy their own clothes, the majority did not respond. However, $42.2 \%$ indicated that their parents or guardians bought their clothes. It can be noted, therefore, that parents/guardians either provided the funds for buying clothes or directly bought the clothes for the respondents.

\section{Features Looked for When Buying Clothes}

The deciding factor that featured more frequently was aesthetics $(47.9 \%)$ followed by comfort (46.2\%) and design/style (43.2\%) (see Table 5). Given that the responses were wide and varied, these figures were significant.
Design and quality were given in lesser degrees. The least features are given were cost and function. This differs from what Brock \& Ulrich (2010) found, that the most frequently discussed and guiding theme was modesty followed by fit when choosing clothes. Modesty in dressing would imply that what is worn would be deemed descent and covers most parts of the body. Thus, modesty as a guiding factor should have been imperative, yet this was not the case. This asserts that for the majority of the students when buying clothes, priority is given to the looks or beauty of an article.

Table 5: Respondents by features looked for when buying clothes

\begin{tabular}{lll}
\hline Feature & n & \% \\
\hline Aesthetics & 271 & 47,9 \\
Comfort & 262 & 46.2 \\
Cost & 70 & 2.4 \\
Design & 245 & 43.2 \\
Fashion & 157 & 27.7 \\
Function & 37 & 6.5 \\
Quality & 127 & 22.4 \\
\hline
\end{tabular}

Multiple responses allowed

\section{Attributes Associated with Different} Articles

The respondents were asked to state the articles owned and the characteristics they associated with them. The attributes given were collapsed into either positive or negative comments. The results are presented in Table 6. All the articles listed were owned by more than $40 \%$ of the respondents. It was noted that only vests received more $(40.5 \%)$ positive comments than negative comments. This is equivalent to $40.5 \%$ of the respondents who owned vests. This is in contrast with the number of articles 
that were assigned negative comments that include high slitted skirts (46.8\%), boob tops (46.1\%), miniskirts (44.3\%), skin-tight trousers (44\%) and close-fitting shirts $(43.3 \%)$ (See Table 6). The fact that these articles got more negative comments could be attributed to the fact that ether they were exposed too revealing. This should be noted alongside the fact that less than half of the total respondents said they owned them. It can be noted that it is impossible to state what can or cannot be worn by college students because there are no written dress codes in the Kenyan public universities. The students have the freedom to choose a variety of articles that please them.

Table 6: Respondents by Attributes associated with articles of clothing

\begin{tabular}{lllllllll}
\hline \multirow{2}{*}{ Article } & \multicolumn{2}{l}{$\begin{array}{l}\text { Those } \\
\text { Owning }\end{array}$} & \multicolumn{2}{l}{$\begin{array}{l}\text { Positive } \\
\text { Comments }\end{array}$} & \multicolumn{2}{c}{$\begin{array}{l}\text { Negative } \\
\text { Comments }\end{array}$} & \multicolumn{2}{l}{$\begin{array}{l}\text { Other } \\
\text { Comments }\end{array}$} \\
& n & \% & n & \% & n & \% & n & \% \\
\hline Vest & 229 & 40.5 & 229 & 40.5 & 51 & 9.0 & 37 & 6.5 \\
Unbuttoned Shirts & 257 & 45.4 & 83 & 14.7 & 189 & 33.4 & 3 & 0.5 \\
Close Fitting Shirts & 238 & 42.0 & 138 & 24.4 & 245 & 43.3 & 20 & 3.5 \\
Shorts & 250 & 44.2 & 152 & 26.9 & 129 & 22.8 & 26 & 4.6 \\
Bare Chest Tops & 251 & 44.3 & 155 & 27.4 & 124 & 21.9 & 31 & 5.5 \\
Mini Skirts & 246 & 43.5 & 31 & 5.5 & 251 & 44.3 & 34 & 6,0 \\
Boob Tops & 233 & 41.2 & 42 & 7.4 & 261 & 46.1 & 30 & 5.3 \\
Skin Tight Dresses & 250 & 44.2 & 53 & 9.4 & 221 & 39.0 & 41 & 7.2 \\
Skin Tight Trousers & 242 & 42.8 & 51 & 9.0 & 249 & 44.0 & 26 & 4.6 \\
Tumbo Cut Tops & 251 & 44.3 & 54 & 9.5 & 226 & 40.0 & 33 & 5.8 \\
High Slitted Skirts & 245 & 43.3 & 35 & 6.2 & 265 & 46.0 & 29 & 5.1 \\
Tight Trousers & 242 & 42.8 & 84 & 14.8 & 205 & 36.2 & 33 & 5.8 \\
Spaghetti Tops & 255 & 45.1 & 103 & 18.2 & 166 & 29.3 & 38 & 6.7 \\
Bareback Tops & 255 & 45.1 & 58 & 10.2 & 225 & 39.8 & 27 & 4.8 \\
Tight Bermuda Shorts & 275 & 48.6 & 60 & 10.6 & 187 & 33.0 & 42 & 7.4 \\
\hline
\end{tabular}

Multiple responses allowed.

Some of the comments given include:

Vests are presentable

Vests are comfortable

Unbuttoned shirts are indecent

Close-fitting shirts are sexy

Shorts are hot

Bare chest tops are provocative

Miniskirts are very sexy
Boob tops are sexually appealing

Skin-tight dresses are scandalous

Skin-tight trousers are tempting

Tumbo cuts are promiscuous

High-slitted skirts are super sexy

Tight trousers are seductive

Spaghetti tops are very sexy 


\section{Modesty in Dress}

Actual standards of modesty may vary from place to place. However, societal norms indicate that modesty in dress is not wearing revealing or suggestive clothes-clothes that are too tight, blouses that are too low-cut, skirts and shorts that are too short, see-through clothes and anything that is too revealing.
Thus, modesty in the dress comes down to dressing in a way that does not call unusual attention to a person. The respondents were given a list of various articles and asked to indicate whether they found them modest or immodest. The respondents were further asked to state whether they found the items modest or immodest.

Table 7: Respondents by whether clothes are considered modest or immodest

\begin{tabular}{l|llll|llll}
\hline Article & \multicolumn{3}{l}{ Modest } & & & \multicolumn{2}{l}{ Immodest } \\
& $\begin{array}{l}\text { Male } \\
\text { n }\end{array}$ & \% & Female & & Male & \multicolumn{3}{l}{ Female } \\
& 236 & 52.4 & 214 & 47.6 & 33 & 51.6 & 31 & 48.4 \\
\hline Vest & 89 & 57.0 & 67 & 43.0 & 172 & 49.0 & 179 & 51.0 \\
Unbuttoned shirts & 163 & 51.9 & 151 & 48.1 & 100 & 51.3 & 95 & 48.7 \\
Close fitting shirts & 184 & 51.1 & 176 & 48.9 & 80 & 52.3 & 73 & 47.7 \\
Shorts & 228 & 53.4 & 199 & 46.6 & 40 & 43.0 & 53 & 57.0 \\
Bare chest tops & 61 & 59.2 & 42 & 40.8 & 197 & 48.6 & 208 & 51.4 \\
Mini skirts & 84 & 46.1 & 98 & 53.8 & 183 & 55.4 & 147 & 44.6 \\
Boob tops & 86 & 43.0 & 114 & 57.0 & 170 & 56.7 & 130 & 43.3 \\
Skin tight Dress & 95 & 51.6 & 89 & 48.4 & 168 & 50.9 & 162 & 49.1 \\
Skin tight trousers & 84 & 46.1 & 98 & 53.9 & 177 & 53.6 & 153 & 46.4 \\
Tumbo Cut tops & 44 & 44.9 & 54 & 55.1 & 216 & 51.9 & 200 & 48.1 \\
High slit skirts & 102 & 42.7 & 137 & 57.3 & 157 & 58.1 & 113 & 41.9 \\
Tight trousers & 121 & 41.0 & 174 & 59.0 & 133 & 62.7 & 79 & 37.3 \\
Spaghetti tops & 87 & 46.8 & 99 & 53.2 & 169 & 52.8 & 151 & 47.2 \\
Bare back tops & 95 & 47.5 & 105 & 52.5 & 157 & 53.6 & 136 & 46.4 \\
Bermuda Shorts & & & & & & &
\end{tabular}

The results point that vests came out as modest by $87.5 \%$ of those who owned them, with more males $(52.4 \%)$ than females $(47.6 \%)$ finding them modest. It is important to note that a vest is a unisex garment, even though more males than females use them in moderate climates. Vests come in two types. The most common one is when used as an undergarment and the second is when used as a waistcoat. As an undergarment, it was unexpected to be considered modest because a shirt or a blouse would have to cover it. Without another garment worn over it, it would seem like incomplete dressing. Bare chest tops were found to be modest too by $82 \%$ of those who owned them, with more males $(53.4 \%)$ than females $(46.6 \%)$ finding them modest. Shorts also were found to be modest at $70 \%$ of those who owned them. $58.2 \%$ of those who owned spaghetti tops found them modest, with more females (59.0) than males (41\%). Shorts refer to short trousers that are either knee length or terminate 3-4 inches above the knee. They range from loosely fitting ones made from light 
East African Journal of Interdisciplinary Studies, Volume 3, Issue 1, 2020

Article DOI: https://doi.org/10.37284/eajis.3.1.264

fabric to tightly fitting ones made from denim

and other heavy fabric.

Table 8: Respondents by whether clothes are considered modest or immodest

\begin{tabular}{lllll}
\hline Article & $\begin{array}{l}\text { Modest } \\
\text { Frequency (n) }\end{array}$ & $\mathbf{( \% )}$ & $\begin{array}{l}\text { Immodest } \\
\text { Frequency (n) }\end{array}$ & $\mathbf{( \% )}$ \\
\hline Vest & 450 & 87.5 & 64 & 12.5 \\
Unbuttoned shirts & 156 & 30.8 & 351 & 69.2 \\
Close fitting shirts & 314 & 61.7 & 195 & 38.3 \\
Shorts & 360 & 70.2 & 153 & 29.8 \\
Bare chest tops & 427 & 82.1 & 93 & 17.9 \\
Mini skirts & 103 & 20.3 & 405 & 79.7 \\
Boob tops & 182 & 35.5 & 330 & 64.5 \\
Skin tight Dress & 200 & 40.0 & 300 & 60.0 \\
Skin tight trousers & 184 & 35.8 & 330 & 64.2 \\
Tumbo Cut tops & 182 & 35.5 & 330 & 64.5 \\
High slighted skirts & 98 & 19.1 & 416 & 80.9 \\
Tight trousers & 239 & 47.0 & 270 & 53.0 \\
Spaghetti tops & 295 & 58.2 & 212 & 41.8 \\
Bare back tops & 186 & 36.8 & 320 & 63.2 \\
Bermuda Shorts & 200 & 40.6 & 293 & 59.4 \\
\hline
\end{tabular}

Multiple responses allowed

Those made from denim can be worn by both genders. The following articles were found to be immodest, high slit skirts $(80.90 \%)$, miniskirts $(79.7 \%)$, unbuttoned shirts $(69.2 \%)$, boob-tops (64.5\%), 'tumbo' cut tops (64.5\%), skin-tight trousers $(64.2 \%)$, skin-tight dresses $(60 \%)$ and Bermuda shorts $(59.4 \%)$. Bermuda shorts refer to short trousers that terminate 3 to 4 inches above the knee, commonly worn by men in Bermuda (a British Overseas Territory in the North Atlantic Ocean). They are commonly worn as business attire or even to cocktail parties. Their use got spread all over the world by tourists. Locally, they are often worn as casual attire. They are usually available in a wide range of colours from neutral grey to brighter hues such as orange, pink or yellow. Also, bare chest tops came across as modest contrary to expectation because they tend to reveal a large portion of the chest. Shorts were deemed modest probably because they weren't too revealing. Slits on skirts are often placed on sides, back or front. High-slitted skirts were found to be immodest, and this can allude to the fact that the slit on the skirt could be revealing too much skin. Miniskirts that were considered immodest conform to similar notions held by institutions like Makerere University that bars students and staff from wearing miniskirts on campus.

\section{SUMMARY OF FINDINGS}

The majority of the respondents resided on campus and bought their own clothes, giving them total freedom to choose what to wear. However, the finances were provided by the parents or guardians. The most outstanding feature that informed choice of dress was aesthetics, followed by comfort and design. 
The least mentioned characteristics were cost and function. Hence, the respondents were more concerned about beauty rather than the cost and function of the article. Unexpectedly, vests and bare chest tops were considered modest. Shorts too were found to be modest, while high-slitted skirts, miniskirts, unbuttoned shirts, boob-tops, tumbo-cut tops, skin-tight trousers, skin-tight dresses, and Bermuda shorts were found to be immodest.

\section{RECOMMENDATIONS}

Based on the study findings, the following recommendations are made: there is a need to develop guidelines that will encourage the students to choose clothes that are fitting and comfortable before beauty can be considered. Guidelines could also be provided for students to select articles that would be deemed modest by both students and staff. Finally, the study recommends that students be enlightened on personal grooming so that what they choose to wear does not embarrass both students and staff.

\section{REFERENCES}

Awasthi, B. (2017). From Attire to Assault: Clothing, Objectification, and Dehumanization-A Possible Prelude to Sexual Violence? Frontiers in psychology, 8, 338.

Barnes, R., \& Eicher, J. B. (Eds.). (1992). Dress and gender: Making and meaning in cultural contexts (Vol. 2). New York: Berg.

Brock, M. K., \& Ulrich, P. V. (2010). Exploring the Apparel Needs and Preferences of Tween Girls and Their Mothers. Clothing and Textiles Research Journal, 95-111.
Butler, M. G. (1975). Clothes: Their choosing, making and care. London: B. T. Batsford.

Damhorst, M. L. (1990). In search of a common thread: Classification of information communicated through dress. Clothing \& Textiles Research Journal, 1-12.

Ehrich, L. C. (1994). The problematic nature of dress for women managers. Women in Management Review, 9 (2), 29-32.

Grammer, K., Renninger, L., \& Fischer, B. (2004). Disco clothing, female sexual motivation, and relationship status: Is she dressed to impress? Journal of sex research, 4l(1), 66-74.

Howlett, N., Pine, K., Orakçığlu, I., \& Fletcher, B. (2013). The influence of clothing on first impressions. Journal of Fashion Marketing and Management: An International Journal, 17, 38-48.

Johnson, K. K., Schofield, N. A., \& Yurchisin, J. (2002). Appearance and dress as a source of information: A qualitative approach to data collection. Clothing and Textiles Research Journal, 20(3), 125-137.

Kaiser, S. B. (1997). The Social Psychology of Clothing. Symbolic appearances in context. 3rd edition. New York: Macmillan.

Kefgen, M., \& Touchie-Specht, P. (1971). Individuality in clothing selection and personal appearance: A guide for the consumer. New York: Macmillan.

Lennon, S. J. (1990). Effects of clothing attractiveness on perceptions. Home Economics Research Journal, 18(4), 303310. 
Lennon, S. J., Fairhurst, A., \& Peatross, F. (1991). Apparel and Furniture Attribute Importance as a Function of SelfMonitoring. Home Economics Research Journal, 19(4), 292-302.

Lennon, S. J., Johnson, K. K., \& Schulz, T. L. (1999). Forging linkages between dress and law in the US, part I: Rape and sexual harassment. Clothing and Textiles Research Journal, 17(3), 144-156.

Lennon, S. J., Johnson, K. K., Noh, M., Zheng, Z., Chae, Y., \& Kim, Y. (2014). In search of a common thread revisited: what content does fashion communicate? International Journal of Fashion Design, Technology and Education, 7(3), 170-178.

Liddell, L. \& Samuels, C. (2004). Clothes and your Appearance. USA: Goodheart-Wilcox.

Olivola, C. Y. \& Todorov, A. (2010). Fooled by first impressions? Re-examining the diagnostic value of appearance-based inferences. Journal of Experimental Social Psychology, 46(2) 315-24.

Pongo, N. A. \& Obinnim, E. (2016). The Relationship between Clothes and First Impressions: Benefits and Adverse Effects on the Individual. International Journal of Innovative Research and Advanced Studies, 3(12) 229-33.

Rudd, N. A., \& Lennon, S. J. (2001). Body image: Linking aesthetics and social psychology of appearance. Clothing and Textiles Research Journal, 19(3), 120-133.

Storm, P. (1987). Functions of Dress. Tool of culture and the individual. New Jersey: Prentice Hall.
Tijana, T., Tomaž, T., \& Čuden, A. P. (2014). Clothes and Costumes as Form of Nonverbal ommunication. Tekstilec, 57(4).

Todorović, T., Čuden, A. P., Košak, K., \& Toporišič, T. (2017). Language of Dressing as a Communication System and its Functions-Roman Jakobson's Linguistic Method. Fibres \& Textiles in Eastern Europe, 5(125): 127-135. 